\title{
Does Aid Work in Conflict? An Empirical Analysis of Pakistan
}

\author{
Sadia Mansoor ${ }^{1}$
}

\begin{abstract}
The effectiveness of aid, among many factors, depends upon the prevailing law and order situation in the recipient economy. Despite receiving relatively large aid inflows, the economy of Pakistan has not performed well and aid effectiveness is often subject to debate. This study has analyzed the role of conflict in explaining economic growth process and aid effectiveness in case of Pakistan, I have constructed conflict index to gauge the role of conflict in Pakistan economy. By using Generalized Method of Moments (GMM) technique and fully modified OLS, the results establish negative association between aid and economic growth in Pakistan. Moreover, through construction of aid-conflict interactive term, it has been established that aid provision in presence of conflict remains ineffectual. Furthermore, results have highlighted that aid made its way to finance arms imports in Pakistan to fight terrorism. This study suggests that Pakistan cannot avail gains from aid without elimination of conflict.
\end{abstract}

Key words: Foreign aid, Conflict, Interstate and Intrastate conflict, Arms trade, Economic Growth, Generalized Method of Moments (GMM), Principal Component Analysis, Fully modified OLS.

\section{JEL codes: D74, F51, F35, O4}

\section{Introduction}

The rationale of aid is more promising than its fallouts. Cheneray and Strout (1966) highlight the importance of aid in reducing twin deficits of developing countries. It implies that by reducing saving-investment gap country can reduce it trade gap as increase in investment results in higher production of exportable items. Thus, higher exports increase per capita income and growth. However, this aid-growth rapport is not that simple. Literature has highlighted that beside promoting economic growth aid plays vital role in making peace or fueling conflict, too. Moreover, purpose of aid also determines consequences and effectiveness of aid. Since WW II, aid to developing countries has increased significantly. Initially, aid was provided to mitigate the negative aftershocks of war but in few states aid was provided for military support. The aims of donor countries and needs of recipients differed over the track of aid.

Currently, most of the aid recipient countries are also in list of fragile states. These countries are fragile because either they are running intrastate conflict or interstate. Many of them are facing terrorism and their economies have borne its cost. After the incident of 9/11, foreign aid has increased significantly to South Asia (especially, to Pakistan) and Middle Eastern conflict zones (Bortolleto,2010 and Sharp, 2015). Countries including Iraq, Syria, Egypt and Jorden, who are also conflict prone

\footnotetext{
${ }^{1}$ Also known as Sadia Anwar as per academic record. Institute of Business Management, Karachi. Pakistan.
} 
territories with low economic growth are among the top recipients of aid. In spite of high foreign aid inflows to these states, average economic growth rate is as low as $2.1 \%$. Here, Pakistan is no exception, high aid inflows failed to reduce twin deficit of Pakistan and growth rate also remained low. Though Pakistan has been part of different programs of IMF since 1958 and received billions of dollars' aid since its making, outcomes and effectiveness of aid are still under question. This study questioned the effectiveness of aid in existence of conflict in Pakistan.

Considering that the rationale behind foreign assistance is to provide funds to low saving economies who are trapped in vicious circle of low economic growth, the situation gets worse when these low saving-low capital formation countries face any internal or external conflict. The countries who run a conflict may not be able to divert the foreign inflows to fill their saving-investment gap. Thus, this aid fungibility makes the aid ineffective to attain economic growth.

An ample literature on Pakistan's economic growth and foreign aid association concludes that aid is not effective in case of Pakistan. Researches have highlighted underlying factors who hinders performance of aid, absence of sound macroeconomic policies, corruption, volatile aid inflows and aid fungibility are the leading determinants of aid ineffectiveness in case of Pakistan (e.g. Ashfaq and Ahmad 2005, Khan and Ahmed 2007, Javid and Qayyum 2011 and Mansoor et al. 2017).

\section{Objectives, Contribution and Significance of the Study}

Existing literature on aid effectiveness in Pakistan has ignored the role of conflict. This study is adding to literature by highlighting the role of conflict in tracing effectiveness of aid in Pakistan from 1972-2017. However, conflict is measured through construction of an index which includes number of terrorist attacks, bomb blasts, unemployment rate, public expenditures on education, inter and intra state conflict, weapons trade, burden of refuges, civilian and military causalities, all these variables have included in index with reference to literature. Moreover, this study has empirically assessed the impact of conflict-associated aid inflows on growth through construction of aid-conflict interactive term. By employing GMM methodology and fully modified OLS, effects of interstate, intrastate and aid inflows have estimated on arms imports of Pakistan. The organization of study is as follows: second part of article presents literature on aidgrowth, conflict-growth and aid-conflict dynamics. In third section, I have discussed historical trends of aid inflows and conflict existence in Pakistan. the model and estimation methodology along with construction of conflict index have presented in section four followed by results and policy implication in section five.

\section{Aid, Growth and Conflict Dynamics}

Aid is said to be effective if it increases economic growth and reduces twin deficit of economy. Moreover, aid reducing poverty and mitigating income inequality also considers effective. Literature is inconclusive in case of aid-growth relationship. Results and impacts of foreign aid on growth varies by country and type of aid. Foreign aid promotes economic growth and helps economy to attain stable socio-economic indicators like education, mortality rate, poverty reduction etc. Moreover, foreign aid increases investment, savings and GDP per capita in developing countries of Sub Saharan Africa and Central Asia (Levy 1988, Khan \& Hoshino 1992, Gomanee et al. 2005, Dollar \& Levin 2006). A few studies have mentioned Botswana, South Korea 
and Taiwan as success stories of aid. Whereas ample literature has underlined the conditional factors in making aid effective; sound macroeconomic policies, noncorruption environment, democracy and financial openness are conditions in which aid can be effective (Boone 1996, Burnside \& Dollar 1997,2000, Javid and Qayyum 2009 etc). Though intuitively its appealing that sound macroeconomic policy environment and financial openness helps in achieving goals of aid, Durbarry (1998) Hansen \& Tarp $(1999,2001)$ have established that aid effectiveness is independent of policies and type of government. Many researches have added to existing literature by underlining that aid becomes ineffective if aid flows are volatile or aid has been provided to corrupt governing bodies (Lensink and Morrissy 2000, Hudson and Mosely 2008, Arellano et al 2009, Mansoor et al 2017 etc).

Pioneer work on conflict-growth relationship by Barro (1991) maintains that political instability increases intrastate arms conflict, this conflict hinders economic growth through destabilization of socio-economic indicators. Studies have found bilateral causality between conflict and growth. Stable growth and high per capita income make people and pressure groups fight for bigger chunk and this result in intrastate conflict, in result conflict increases as people again get into fight over economic means for survival (Keen 2000, Bates 2001).

Studies have maintained that wealth and abundant natural resources can erupt conflict. Olsson (2006) find significant positive relationship between natural resources and conflict in Botswana. Similarly, Wizarat (2014) empirically establishes that natural resources become curse for developing countries as power greedy groups and international agencies create conflict in these countries to get possession over natural resources. Hence, conflict emerged for possession and rent seeking hampers economic growth of developing countries.

On other way round, Homer-Dixon (1994) and Fearon and Laitin (2002) establish that societies with wealth and noteworthy financial assets can invest to have better management system for asset protection so that violence conflict decreases or remained under control with increase in wealth. Collier and Hoeffler $(1998,2004)$ find a nonlinear relationship between economic resources and the risk of armed conflicts. Using Probit and tobit regressions, they attribute natural resources as a potential source of armed conflict. Initially, conflict and risk of war increases with exploration of natural resources, but risk of further increase in conflict decreases when income inequality decreases with increase in per capita income derived from these natural resources. A line of research has found that aid triggers conflict and type of aid also plays its role. Funds provided under military aid umbrella are more likely to prompt inter as well as interstate conflict. considering that aid is fungible, funds and grants to conflict prone economies can further increase the risk of conflict as governments or military powers may use this funding to curb conflict which can respond back. Aiding intrastate conflict affected country can have even severe consequences if aid makes its way to military expenditure rather diverted to reduce twin gap of economy. This may increase interstate or regional conflict because war of arms and power among neighboring country increases with increase in military aid [Addison and Murshed 2001, Collier and Hoeffler 2007, Collier and Benedikt 2009]. For instance, figures show that nearly 40 percent of military expenditure in African countries have been financed through aid which resulted in up surging conflict and low economic growth. 
International committee of the Red Cross (ICRC) has added to the fact that after cold war large surplus of weapons was transferred to developing countries as a part of direct or military aid which result in inter and intra-state conflict increment. In context to military support and coalition support, many developing countries received heavy amount of armament from arms exporting countries and this transfer increased regional disparities and imbalance of power. Historically, power countries (US and Soviet Union) transferred weapons to Iran, Iraq, Syria and Egypt after the World War II under the heading of military aid but this transfer fueled inter and intra state conflicts in these countries. Factually, aid related to military expenditures, food, transportation and supplies increased the level of conflict and violence in Chechnya, Tajikistan, and Somalia, too (e.g. Kinsella 1994, Anderson 1999).

Recent literature on foreign aid and conflict nexus shows that funds provision to conflict prone countries lead to increase military fatalities (Tao et al, 2016). Strandow et al. (2013) also find that aid promotes conflict and results in increment of military fatalities by as much as 138 percent. On the contrary, Collier and Hoeffler (2002) maintain in past that aid can reduce probability of conflict by 30 percent within five years. Another line of literature has highlighted that the role of aid and conflict in process of democracy. Conflict may trigger during process of democratization (Mansfield and Snyder 1997, Snyder 2000) but aid for democracy can reduce intrastate conflict because aid can finance all promises related to infrastructure development, job creation, access to financial resources and openness [e.g. Fearon 1998, Narang and Nelson 2009, Savun and Tirone 2011]. Berman et al (2011) also supports the phenomena of aiding democracy to reduce conflict, they assess a case study of Iraq in post 9/11 scenario and uphold that improved service provision reduces insurgent violence because aid used by the public sector for provision of public goods resulted in better literacy rate and living standard.

\section{Dynamics of Aid Inflow to Pakistan and Conflict Existence}

Most of the aid inflows to Pakistan have come from bilateral sources and major contribution has been made by the USA. Anwar and Michaelowa (2004) calculated that more than 72 percent of official development assistance to Pakistan has come from bilateral sources, and out of which nearly half was provided by a single donor i.e. USA. Since 9/11, Pakistan has received nearly USD 32 billion from USA and almost 60 percent of this aid comes under security funds which Pakistan utilized to battle conflict.

Unlike aid flows to other countries, the aid in Pakistan seems to be dependent more on geo-political factors than underlying development needs. Considering large share of aid from bilateral source, it is argued that aid in Pakistan appears to be dependent more on security and military consideration than underlying economic situation or development needs. An analysis of period in which high aid inflows were received also support this assertion. For example, the aid inflow during 1960s and 1970s was the result of Pakistan's signing of mutual defense assistance agreements ${ }^{2}$ with USA in pre cold war era. Similarly, aid inflow during 1980s can be contextualized in perspective of Afghanistan

\footnotetext{
2 In 1954, SEATO (Southeast Asia Treaty Organization) was formed with an objective to arrest growing influence of communism. The member countries include: USA, France, Great Britain, New Zealand, Australia, Philippines, Thailand and Pakistan. In 1955, Turkey, Iraq, Great Britain, Iran and Pakistan signed Baghdad Pact to protect the region against communist encroachment. In 1959, it was named as CENTO (the Central Treaty Organization) when Iraq pulled out of the Pact.
} 
war. During 1990s, the USA and other multilateral donor agencies placed sanctions on economic assistance to Pakistan as Afghan war ended. Aid inflows to Pakistan dropped further after execution of nuclear tests in May 1998 and overthrowing of democratically elected government by the military in October 1999. Being under several sanctions from USA, Pakistan consequently received lowest average annual aid during 1990s.

However, the sanctions were waived after incident of 9/11 attacks and Pakistan's subsequent joining of coalition of war against terror. Pakistan received highest average annual aid of approximately USD 2.9 billion during period 2010-14. The majority of the funds have come under the Coalition Support Fund (CSF) which is the reimbursement of the cost of fighting terrorism over and above regular military cost incurred by the Pakistan. The other security-related accounts under which aid inflows have received are the Pakistan Counterinsurgency Fund/Counterinsurgency Capability Fund (PCF/PCCF). There was a clear shift in US aid strategy in 2010 when USA offered non-military aid to Pakistan under Enhanced Partnership with Pakistan Act, also known as the KerryLugarBerman Act. The act committed USD 1.5 billion per year to Pakistan as nonmilitary aid from 2010 to 2014. Being part of war on terror, the military expenditures in Pakistan have also observed a significant increase. For instance, during 2015-16, Pakistan has spent around USD 1,630 million on arms imports. The official accounts show that from during 2007-2016, Pakistan has imported arms worth on average USD 1,072 million per year. The compound annual growth rate of military expenditure is 14 percent from 20072016.

This study contributes to the ongoing debate of aid effectiveness by analyzing case of Pakistan. The motivation of this study is to estimate the impact of foreign aid vis-à-vis conflict on economic growth of Pakistan. The majority of empirical literature on Pakistan has highlighted that foreign aid has been ineffective in promoting economic growth. In this regard, I want to analyze and highlight the role of conflict in aid effectiveness. The rationale of foreign aid states that aid is needed to fill saving-investment gap to accelerate economic growth. However, conflict prone country's fungible aid issue can divert financial inflows to military and non-development expenditures which results in making aid ineffective to promote economic growth and combating conflict.

Pakistan has long history to be involved in inter-state conflict. At the same time, intrastate conflict has also increased especially after Pakistan involvement in global war on terror. Political instability, high unemployment rate, law and order conditions, unavailability or lack of access to financial and physical resources for general public, low school enrollment rate, low public spending on education sector, religious and ethnic issues can be attributed for increase in conflict in Pakistan. Three major wars with India, increased terrorist attacks in the aftermath of 9/11, and burden of afghan refugees are the main origins of conflict in Pakistan.

\section{ESTIMATION METHODOLOGY AND DATA}

Economic growth of any country depends on combination of inputs (labor L, financial and physical capital K) with reference to their elasticities. Availability and responsiveness of inputs enables an economy to increase exportable production (To).

$$
\begin{gathered}
Y=f\left(L^{\alpha}, K^{\beta}\right) \\
Y=f\left(L^{\alpha}, K^{\beta}, T o^{\gamma}\right)
\end{gathered}
$$


An economy suffering with low financial capital and savings will require foreign assistance to reduce saving investment gap to increase output. This need is rationale behind foreign aid and foreign debt.

$$
Y=f\left(L^{\alpha}, K^{\beta}, T o^{\gamma}, \text { Aid, Debt }\right)
$$

The problem emerges when recipient government faces any conflict. To combat that conflict, government divert these financial inflows to reduce the level of conflict. Developing countries, being already faced with low saving-low investment trap, thus look for foreign aid and debt to deal with conflict. Similarly, low revenue (R) collection also leads to increase in foreign assistance and debt dependency. In this study, an index has been constructed to assess the impact of conflict on economic growth. Construction of Conflict Index of Pakistan In this study, I have constructed an index to measure the level of conflict in Pakistan. The value of index implies that higher the value of index, higher the level or intensity of the conflict. Principle Component Analysis (PCA) has used to construct this index. The first component of PCA explains maximum variations of the data, while the second and third components explain the remaining variations. Following literature, I have added refugee burden (Ref), unemployment rate (Ue), drone attacks (Da), fatalities due to conflict (F), education expenditure (Ex), arms imports (Arms), suicide attack and terrorist incidents (ST), intra (Is) and interstate (Ic) conflict in index. The weights of included variables have derived through first principal component as it represents the highest correlation. Finally, weights $(\dot{\omega})$ have been assigned through normalizing the values of vector 1 . The conflict index used in this analysis is based on the following equation:

$$
\begin{aligned}
& \text { Conflict Index } \\
& \text { ( ) } \\
& \text { ( ) ( ) } \\
& =\dot{\omega}_{1}(R e f)-\dot{\omega}_{2}(E X)+\dot{\omega}_{3}(U e)+\dot{\omega}_{4}(D a)+\dot{\omega}_{5}(F)+\dot{\omega}_{6}(S T) \\
& +\dot{\omega}_{7}(I c)+\dot{\omega}_{8}(I s)+\dot{\omega}_{9}(\text { Arms }) \\
& =0.015(\text { Ref })-0.010(E X)+0.046(U e)+0.188(D a) \\
& +0.201 F+0.19 S T+0.155 \text { Ic }+0.141 \text { Is }+0.168 \text { Arms }
\end{aligned}
$$$$
\text { ( ) ( ) }
$$

Figure 4.1 presents historical trend of constructed conflict index. I have also checked the stationarity of this series and reported the results in Table 4.1.

---add figure 4.1----- from annexure

The volatility in conflict index highlights the incidence and intensity of conflict over the long period of time. After the Indo-Pak war (1971), Pakistan faced interstate conflict which resulted in separation of east and west Pakistan. Implementation of nationalization policy increased income inequality, unemployment and poverty in the economy in 1970s. During the same time period, Pakistan economy suffered with flood and drought on almost alternative years. The decline in per capita income and increase in inflation triggered intrastate conflict. After Afghan war, Pakistan economy came under severe pressure when notable amount of Afghan refugees migrated to Pakistan in 1979. This was the time when concept of religious radicalization was pursued and Pakistani Taliban emerged to take part in Afghan war. The aftermath of all was increased inter and intrastate conflict in 1990s and 2000s. The prevalence of conflict peaked 
further after the 9/11 attacks and Pakistan's subsequent joining of global war on terror. Suicide attacks rattled the cities and garrisons of Pakistan and more than 50,000 lives were lost in a period of 15 years. Military expenditures also increased tremendously along with heavy arms imports. The deterioration in law and order situation also resulted in reducing foreign direct investments decline and below potential GDP growth.

\section{--------Add table 4.1 from annexure------ The \\ Methodology and Empirical Equations}

In this study Generalized Method of Moment (GMM) technique has been employed to estimate the effectiveness of foreign aid in the presence of conflict. Hansen (1982) developed the generalized method of moments (GMM) model and it has been widely used due to its several advantages. Particularly, GMM is useful in case of endogenity, Hansen and Tarp (2000), Rajan and Subramanian (2005) have highlighted the existence of potential endogenity between aid and economic growth, they have also suggested that GMM methodology is appropriate to assess the relationship between aid and growth. Specifically, following equations have been estimated to assess the impact of foreign aid and conflict on Pakistan economy from 1972 to 2017.

$$
\begin{aligned}
& \left(\ln Y_{2017}-\ln Y_{1972)} i=a_{0}+a_{1} \ln (\mathrm{Aid}) i+a_{2} \ln (\mathrm{L}) i+a_{3} \ln (\mathrm{K})_{i}+a_{4} \ln (\mathrm{To})_{i}+a_{5}(\mathrm{FDI}) i+\right. \\
& a_{6} \ln (\mathrm{Gx})_{i}+\mu \quad------(4.1) \\
& \left(\ln Y_{2017}-\ln Y_{1972}\right)_{i}=a_{0}+a_{1} \ln (\text { Conflict })_{i}+a_{2} \ln (\mathrm{L})_{i}+a_{3} \ln (\mathrm{K})_{i}+a_{4} \ln (\mathrm{To})_{i}+a_{5} \\
& (\mathrm{FDI}) i+a_{6} \ln (\mathrm{Gx})_{i}+\mu \quad------(4.2) \\
& \left(\ln Y_{2017}-\ln Y_{1972}\right)_{i}=a_{0}+a_{1} \ln (\mathrm{Aid}) i+a_{2} \ln (\mathrm{L}) i+a_{3} \ln (\mathrm{K})_{i}+a_{4} \ln (\mathrm{To})_{i}+ \\
& a_{5}(\mathrm{FDI}) i+a_{6} \ln (\text { Conflict }) i+a_{7} \ln (\mathrm{Gx})_{i}+\mu
\end{aligned}
$$

The dependent variable is real GDP per capita (Y) from 1972-2017. Literature maintains positive impact of labor, capital and trade openness on economic growth. Here, gross fixed capital formation series has used as a proxy of capital. While impact of foreign aid and foreign direct investment on economic growth varies by country's need and utilization. Following Burnside and Dollar (2000), an aid-conflict interactive term has constructed in equation (4.4). This term implies that aid inflows associated to conflict have impact on economic growth of Pakistan. By rearranging equation (4.3), following equations assess the impact of aid inflows associated to conflict on economic growth.

$$
\begin{aligned}
& a_{4} \ln (\mathrm{To})_{i}+a_{5}(\mathrm{FDI})_{i}+a_{6} \ln (\mathrm{Gx})_{i}+\mu \\
& \text { term })+a_{2} \ln (\mathrm{L}) i+a_{3} \ln (\mathrm{K}) i+
\end{aligned}
$$

$i(\ln Y 2017-\ln Y 1972) i=a_{0}+$ $a_{1} \ln$ (Aid Conflictinteractive

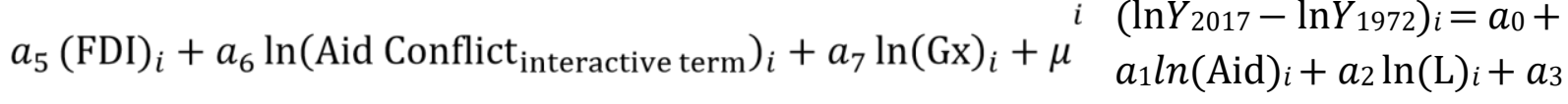
$\ln (\mathrm{K})+a_{4} \ln (\mathrm{To})_{i}+$

check the robustness of results, I have re-estimated the equations $4.3 \& 4.4$ through Fully Modified OLS method.

\section{Arms Trade and Military Expenditure}

When government faces conflict, military expenses (M) increases along with non-development expenditures $(\mathrm{Gc})$. Literature also highlight that revenue collection in developing countries are far lower than their expenditures and situation get even worse when there is a conflict. In the 
presence of any war or conflict, government diverts its financial resources from development avenues to military expenditures to fight conflict.

Considering that economic welfare (W) is a function of government spending, following equations express the consumption pattern of government:

$$
\begin{aligned}
& \qquad W=f(G d, G c, M) \\
& \text { Maximize } \mathrm{W}(G d, G c, M)=G_{d}^{\alpha}, G_{c}^{\beta}, M^{\gamma}
\end{aligned}
$$

Revenue collection in developing and low income countries are usually lower than public sector expenditures, hence

$$
\mathrm{R} \leq\left(P_{d} G d+P_{c} G c+P_{M} M\right) \text { Here }
$$

the need for aid arises to fill income-expenditure gap.

$$
\mathrm{R}+\mathrm{Aid}=P_{d} G d+P_{c} G c+P_{M} M
$$

By using (3.1) and (3.2), the langrangian will be

$$
\mathcal{L}=G_{d}^{\alpha}, G_{c}^{\beta}, M^{\gamma}+\lambda\left(\mathrm{R}+\mathrm{Aid}-P_{d} G d-P_{c} G c-P m M\right)
$$

Here, Gdo and Gco are threshold levels of public expenditures and Mo is threshold level of military expenditures to fight conflict. By normalizing (4 a), I get

Maximize $\mathrm{W}(G d, G c)=\alpha \ln (G d-G d o)+\beta \ln (G c-G c o)+\gamma \ln (M-M o)$

Following first order condition, I have

$$
\begin{gathered}
\frac{\partial W}{\partial G d}=\frac{\alpha}{(G d-G d o)}-\lambda P_{G d}-\lambda P_{m} \\
\frac{\partial W}{\partial G c}=\frac{\beta}{(G c-G c o)}-\lambda P_{G c}-\lambda P_{m} \\
\frac{\partial W}{\partial M}=\frac{\gamma}{(M-M o)}-\lambda P_{G c}-\lambda P_{G d} \\
\frac{\partial W}{\partial \lambda}=R+A i d-P_{d} G d-P_{c} G c-P m M
\end{gathered}
$$

by solving for Gd, Gc, M and langrangian multiplier $(\alpha, \lambda)$, I get

$$
\begin{gathered}
G d^{*}=\frac{\beta}{\lambda P_{d}}+\lambda P_{d}+\lambda P m \\
G c^{*}=\frac{\beta}{\lambda P_{c}}+\lambda P_{c}+\lambda P m+\lambda P_{d} \\
M^{*}=\frac{\gamma}{\lambda P_{m}}+\lambda P_{c} \\
\lambda=\frac{\alpha+\beta+\gamma}{R+\text { Aid }-P_{d} G d-P_{c} G c-P m M}
\end{gathered}
$$

After substituting the values of $\mathrm{Gd}, \mathrm{Gc}$ and $\mathrm{M}$ in langrangian multiplier, I get

$$
\begin{aligned}
G d^{*} & =\frac{\alpha\left(R+A i d-P_{d} G d-P_{c} G c-P m M\right)}{(\alpha+\beta+\gamma) P_{d}}+G d o \\
G c^{*} & =\frac{\beta\left(R+A i d-P_{d} G d-P_{c} G c-P m M\right)}{(\alpha+\beta+\gamma) P_{c}}+G c o \\
M^{*} & =\frac{\gamma\left(R+A i d-P_{d} G d-P_{c} G c-P m M\right)}{(\alpha+\beta+\gamma) P_{d}}+M o
\end{aligned}
$$

This optimal value of military expenditures expresses the expenditures on arms imports, internally displaced people's insurances, resettlement cost in operation area and cost of maintaining desirable level of military soldiers and equipment to fight conflict. This cannot be financed solely from revenue, increase in these expenditures demand more aids and debts. Pakistan, being part of war on terror, also utilized coalition support funds to finance these exponentially increased military expenditures since 2007 . 
In presence of conflict, military expenditure increases so as arms trade. Following equation asserts that impact of conflict on arms imports (AT) in case of Pakistan.

$\left(A T_{2017}-A T_{1972}\right)_{i}=a_{0}+a_{1}(\text { Aid })_{i}+a_{2} \ln (\text { Conflict })_{i}+a_{3}(\mathrm{CSF})_{i}+a_{4}(\mathrm{M})_{i}+\mu$

$\left(A T_{2017}-A T_{1972}\right)_{i}=a_{0}+a_{1}(\mathrm{Aid}) i+a_{2}(\text { Inter })_{i}+a_{3} \ln (\text { Intra })_{i}+a_{4}(\mathrm{CSF})_{i}+a_{5}(\mathrm{M})_{i}+$ $\mu$----- (4.7)

Since 9/11, Pakistan received coalition support fund (CSF) to fight conflict, and therefore I have used dummy for CSF in this analysis. In Equation (4.6), I have replaced conflict index with inter and intra state conflict.

\section{Data Source and Variables}

----- add table 4.2 from annexure-----

\section{ESTIMATION RESULTS AND DISCUSSION}

This study has empirically assessed the aid effectiveness in case of Pakistan. This study has employed GMM methodology to analyze the dynamics of foreign aid, conflict and economic growth. The results in Table 5.1 show the negative association between foreign aid inflows and economic growth; one percent increase in foreign aid inflows leads to 0.07 percent decrease in economic growth. The robustness of the result is examined in Table 5.1. Foreign aid has consistently negative coefficient. Findings of this study are consistent with the results of Doucouliagos and Martins (2005), Javid and Qayyum (2011). Rajan and Subramanian (2005) also state that aid inflows can reduce competitiveness of the country which can result in low exportable production, hence, low economic growth. Another reason behind this finding can be Pakistan's reliance on bilateral aid. Baure (1982) and Radelet (2006) emphasized that bilateral aid is mostly politically motivated aid and not for economic needs of economy. Existence of corruption and political instability can also be contributing factors in making aid ineffective. In this analysis, I have empirically estimated the impact of conflict on foreigngrowth relationship. Results of Eq. 4.3 show that in the presence of conflict, aid reduces economic growth by 0.05 percent. Similarly, conflict negatively effects economic growth by 0.07 percent when aid sent to conflict prone Pakistan economy.

The results of equation (4.4) suggest that aid inflows associated to conflict control also portrayed negative impact on Pakistan economy. Aid affiliated to conflict decreased economic growth by 0.01 percent. This result is also in line with existing literature. As many studies suggested that aid provided to fight conflict can further boost the level and intensity of conflict (Narrang. 2015, Strandow et al. 2016).

\section{ADD TABLE 5.1 FROM ANNEXURE}

To check the robustness of results, I have re-estimated Eq. 4.3 through Fully Modified Ordinary Least Square (FMOLS) method. The results presented in Table 5.2 are consistent with the results of GMM estimations. The coefficients and signs of control variables are also steady throughout the analysis. As highlighted in the literature, labor force, trade openness, and gross fixed capital formation have significantly positive impact on economic growth of Pakistan. However, foreign direct investment has negative impact on economic wellbeing; historically Pakistan has experienced that the most of the foreign direct investment did not bring technology to Pakistan and this eventually resulted in capital flight out of the economy. This result is also consistent the results of Adewumi (2007) and Rahman (2015). 
Findings of this study show that existing conflict has significantly negative impact on economic growth of Pakistan even in the absence of foreign aid in Eq 4.2. This also suggest robustness of in findings. Results presented in Table 5.1 show that one percent increase in conflict reduces economic growth rate by $0.14 \%$ in Pakistan. These results are in line with findings of Polachek and Sevastianova (2012). They state that annual economic growth reduces by 0.01-0.13 percentage points if there is any ongoing civil war. Similarly, interstate conflict reduces growth by 0.18-2.77 percentage points. As Pakistan has been suffering with both inter and intra state conflicts, findings of negative association between growth and conflict are per expectation. Also, the findings have supported the construction of index. All the employed variables in index have meaningful relationship with emergence of conflict in Pakistan. For instance, literature maintains that inflow of refuges leads to increase in ethnic conflict (Newland, 1993). Similarly, Brown (1993) states that refugee burden increases security cost and military expenditures. After an increase in refugee burden since 1979, Pakistan has faced a tremendous rise in interstate as well as intrastate and ethnic conflict. Considering limited fiscal space due to low revenue mobilization, Pakistan had to seek foreign aid to accommodate refugees. According to Gearon (2013), reduction in education expenditures leads to increase in terrorism. Unesco's report ${ }^{3}$ also suggests that education attainment can prevent a country from extremisms and terrorism. Pakistan has received a handsome amount of multilateral aid to finance education sector expenditures.

Cramer (2011) presents a generous literature to establish positive relationship between conflict and unemployment. Due to high level of unemployment, more people get involve in violent conflict. The cost of this conflict is reduction in economic growth and further increment in unemployment. Mandel (1998) states that conflict has an economic cost. Increase in arms imports reduces development expenditure of developing countries. However, this arms trade has positive impact on supplier's economic growth. Craft and Smaldone (2003) maintain positive relationship between arms trade and conflict. They also find negative impact of war and arms' imports on economic growth of sub-Saharan Africa. In case of Pakistan, fighting conflict results in an increase in arms imports so as aid requirement. Drone attacks increased cost of settlement and insurance for Pakistan. Pakistan has lost number of soldier and personals in interstate and intrastate conflict, which results in increase in transfer payment burden on government.

Findings of this study show that aid-conflict interactive term also has negative impact on economic growth. Historically, most of the aid provided to Pakistan was associated to refuge settlement, conflict mitigation or to finance war on terror. The aid has not been provided to fill the saving-investment gap or to promote economic growth. Since aid inflows coincide with conflict, it has negative impact on Pakistan's economic growth.

This study has empirically estimated the association of conflict with arms imports in case of Pakistan. Results in Table 5.3 indicate that due to increase in conflict, arms imports have significantly increased in Pakistan. One percent increase in conflict leads to 1.6 percent increase in arms imports, enlarging the military expenditures ultimately. While, coalition support funds and aid to fight terrorism has insignificantly positive association with arms imports. It can also be assessed that arms imports have significantly increased due to interstate conflict and intrastate conflict have insignificant positive association with arms imports in case of Pakistan.

${ }^{3}$ The report is available at http://unesdoc.unesco.org/images/0024/002477/247764e.pdf 


\section{IMPLICATION}

This study has contributed in aid effectiveness literature by analyzing the role of conflict. Results of this study show that at the time of the conflict, the aid inflows are rendered ineffective. One explanation could be that most of the aid flows make their way towards military expenditures at the time of conflict. Further, without restoring the prevailing law and order condition in a country, the developmental activities being aimed by the aid inflows are also not properly pursued. A case in point is US aid inflows towards Pakistan for development expenditures on account of Kerry-Lugar support program. The aid inflows prove to be ineffective since the law and order situation was not conducive for any development activities. The policy implication for both donor and recipient of aid is to first direct their efforts towards reducing conflict in the country.

\section{REFERENCES}

Addison, T. and Murshed, S.M., 2001. From conflict to reconstruction: Reviving the social contract (No. 2001/48). WIDER Discussion Papers//World Institute for Development Economics (UNU-WIDER).

Adewumi, S., 2007. The impact of FDI on growth in developing countries: An African experience.

Ahmed, M.M., 2010. External debts, growth and peace in the Sudan: Some serious challenges facing the country in the post-conflict era.

Anderson, M.B., 1999. Do no harm: how aid can support peace--or war. Lynne Rienner Publishers.

Anwar, M. and Michaelowa, K., 2006. The political economy of US aid to Pakistan. Review of Development Economics, 10(2), pp.195-209.

Backer, D., Bhavnani, R. and Huth, P. eds., 2016. Peace and Conflict 2016. Routledge. 
Bauer, P. and Yamey, B., 1982. Foreign aid: What is at stake?. The public interest, (68), p.53.

Berman, E., Shapiro, J.N. and Felter, J.H., 2011. Can hearts and minds be bought? The economics of counterinsurgency in Iraq. Journal of Political Economy, 119(4), pp.766819. - Bortolleto (2010). American Foreign Aid: Recent Trends in Goals and

Allocation. Social Sciences Journal, 10(1), p.7.

Brown, M.E. ed., 1993. Ethnic conflict and international security. Princeton University Press.

- $\quad$ Burnside, C. and Dollar, D., 1997. Aid spurs growth-in a sound policy environment. Finance and Development, 34(4), p.4.

- $\quad$ Burnside, C. and Dollar, D., 2000. Aid, policies, and growth. American economic review, 90(4), pp.847-868.

Burnside, C. and Dollar, D., 2004. Aid, policies, and growth: reply. American economic review, 94(3), pp.781-784.

- $\quad$ Chenery, H.B. and Strout, A.M., 1968. Foreign assistance and economic development: Reply. The American Economic Review, 58(4), pp.912-916.

Collier, P. and Dollar, D., 2001. Aid, risk and the special concerns of small states. Small states in the global economy, pp.11-38.

Collier, P. and Dollar, D., 2002. Aid allocation and poverty reduction. European economic review, 46(8), pp.1475-1500.

Collier, P. and Hoeffler, A., 2002. Aid, policy and peace: Reducing the risks of civil conflict. Defence and Peace Economics, 13(6), pp.435-450.

- $\quad$ Collier, Paul, and Benedikt Goderis. "Does aid mitigate external shocks?." Review of Development Economics 13, no. 3 (2009): 429-451.

Craft, C. and Smaldone, J., 2003. Arms imports in sub-saharan Africa: Predicting conflict involvement. Defence and peace economics, 14(1), pp.37-49. - Cramer, C., 2011. Unemployment and participation in violence.

- Dalgaard, C.J. and Hansen, H., 2001. On aid, growth and good policies. Journal of development Studies, 37(6), pp.17-41.

De Ree, J. and Nillesen, E., 2009. Aiding violence or peace? The impact of foreign aid on the risk of civil conflict in sub-Saharan Africa. Journal of Development Economics, 88(2), pp.301-313.

- De Waal, A., 1997. Democratizing the aid encounter in Africa. International Affairs, 73(4), pp.623-639.

Doucouliagos, H. and Paldam, M., 2009. The aid effectiveness literature: The sad results of 40 years of research. Journal of Economic Surveys, 23(3), pp.433-461.

- Easterly, W., 2001. The elusive quest for growth: economists' adventures and misadventures in the tropics. MIT press.

- $\quad$ Easterly, W., 2003. Can foreign aid buy growth?. Journal of economic

Perspectives, 17(3), pp.23-48.

- $\quad$ Gearon, L., 2013. The counter terrorist classroom: Religion, education, and security. Religious Education, 108(2), pp.129-147.

Hansen, H. and Tarp, F., 2000. Aid effectiveness disputed. Foreign Aid and Development: lessons learnt and directions for the future, pp.103-128.

Khan, M.A. and Ahmed, A., 2007. Foreign aid-blessing or curse: Evidence from Pakistan. The Pakistan Development Review, pp.215-240. 
\begin{tabular}{ll}
\hline Paris, France & November 2-4,
\end{tabular}

Khan, M.A. and Ahmed, A., 2007. Foreign aid-blessing or curse: Evidence from Pakistan. The Pakistan Development Review, pp.215-240.

Kinsella, D., 1994. Conflict in context: Arms transfers and third world rivalries during the cold war. American Journal of Political Science, pp.557-581.

- $\quad$ Lensink, R. and Morrissey, O., 2000. Aid instability as a measure of uncertainty and the positive impact of aid on growth. The Journal of Development Studies, 36(3), pp.3149. - Lensink, R. and White, H., 2000. Assessing aid: a manifesto for aid in the $21 \mathrm{st}$ century?. Oxford Development Studies, 28(1), pp.5-18.

- Lensink, R. and White, H., 2001. Are there negative returns to aid?. Journal of development Studies, 37(6), pp.42-65.

- $\quad$ Mandel, R., 1998. Exploding myths about global arms transfers. Journal of Conflict Studies, 18(2).

MANSOOR, S., BAIG, M.A. and JAVID, M., 2017, July. FOREIGN AID VOLATILITY AND ECONOMIC GROWTH: A CASE STUDY OF PAKISTAN.

In 3rdAcademic International Conference on Law, Economics and Finance (p. 6).

- $\quad$ McGillivray, M. and Noorbakhsh, F., 2007. Aid, conflict and human development (No. 2007_03).

- $\quad$ Muhammad, J. and Qayyum, A., 2011. Foreign aid-growth nexus in Pakistan: role of macroeconomic policies.

- $\quad$ Muhammad, J. and Qayyum, A., 2011. Foreign aid-growth nexus in pakistan: role of macroeconomic policies.

- Narang, N., 2015. Assisting uncertainty: how humanitarian aid can inadvertently prolong civil war. International Studies Quarterly, 59(1), pp.184-195.

Nasir, M., Rehman, F.U. and Orakzai, M., 2012. Exploring the nexus: Foreign aid, war on terror, and conflict in Pakistan. Economic Modelling, 29(4), pp.1137-1145. Newland, K., 1993. Ethnic conflict and refugees. Survival, 35(1), pp.81-101.

- $\quad$ Polachek, S.W. and Sevastianova, D., 2012. Does conflict disrupt growth? Evidence of the relationship between political instability and national economic performance. The Journal of International Trade \& Economic Development, 21(3), pp.361-388.

- $\quad$ Polachek, S.W. and Sevastianova, D., 2012. Does conflict disrupt growth? Evidence of the relationship between political instability and national economic performance. The Journal of International Trade \& Economic Development, 21(3), pp.361-388.

- $\quad$ Polman, L., 2010. The crisis caravan: what's wrong with humanitarian aid?.

Metropolitan Books.

- $\quad$ Radelet, S., 2006. A primer on foreign aid.

- $\quad$ Rahman, A., 2015. Impact of foreign direct investment on economic growth: Empirical evidence from Bangladesh. International Journal of Economics and Finance, 7(2), p.178. - Rajan, R.G. and Subramanian, A., 2005. Aid and growth: What does the crosscountry evidence really show? (No. w11513). National Bureau of Economic Research. Rajan, R.G. and Subramanian, A., 2005. Aid and growth: What does the cross-country evidence really show? (No. w11513). National Bureau of Economic Research. - Sachs, J.D., 2006. How aid can work. The New York Review of Books, 53(20). - Savun, B. and Tirone, D.C., 2011. Foreign aid, democratization, and civil conflict: how does democracy aid affect civil conflict?. American Journal of Political Science, 55(2), pp.233-246.

Schulze, K.E., 2016. The Arab-Israeli Conflict. Taylor \& Francis. 
Sharp, J.M., 2015, June. US foreign assistance to the Middle East: Historical background, recent trends, and the FY2016 request. LIBRARY OF CONGRESS WASHINGTON DC CONGRESSIONAL RESEARCH SERVICE.

Strandow, D., Findley, M.G. and Young, J.M., 2014. Foreign aid and the intensity of violent armed conflict. Unpublished working paper.

- Svensson, J., 1999. Aid, growth and democracy. Economics \& politics, 11(3), pp. 275297.

Tao, R., Strandow, D., Findley, M., Thill, J.C. and Walsh, J., 2016. A hybrid approach to modeling territorial control in violent armed conflicts. Transactions in GIS, 20(3), pp.413425.

\section{Annexure}

\section{Figure 4.1 : Conflict Index in Pakistan}

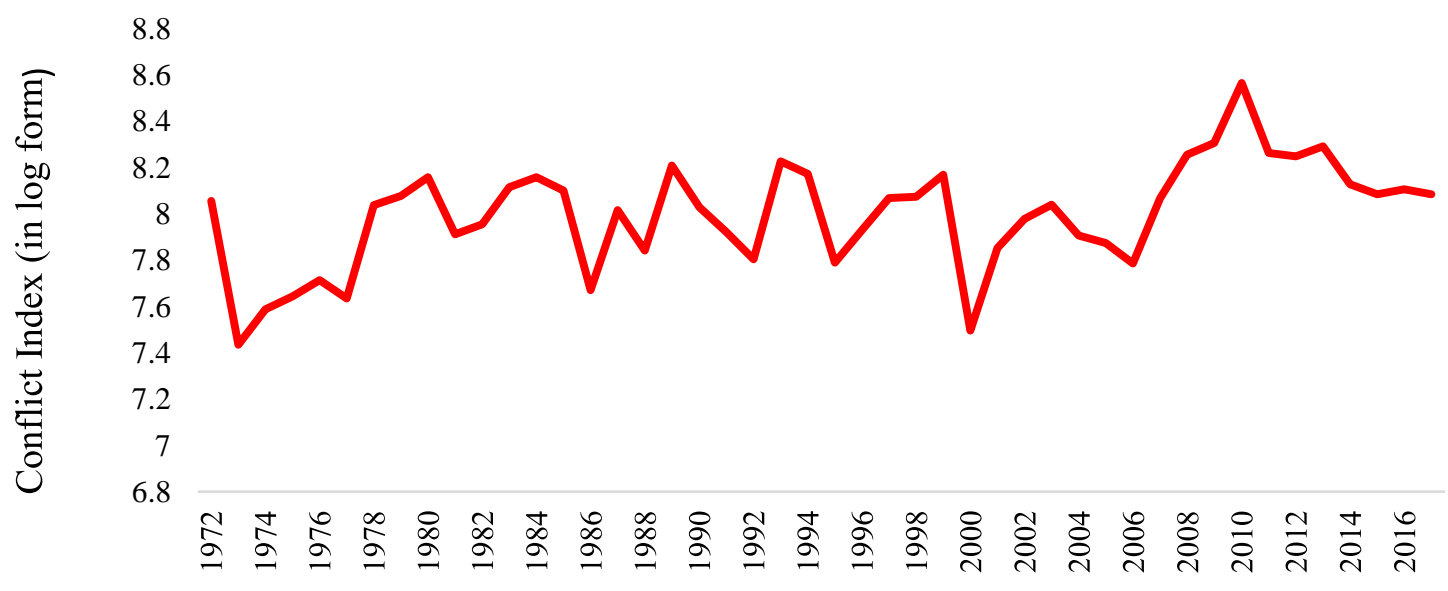

Table 4.1 Unit Root Test of Conflict Index

t Statistic

Prob.*

\begin{tabular}{ll|l|l}
\hline \hline Augmented Dickey-Fuller test statistic & & -3.8418 & 0.0051 \\
Test critical values: & $1 \%$ level & -3.5925 & \\
& $5 \%$ level & -2.9314 &
\end{tabular}


*MacKinnon (1996) one-sided p-values. 


\begin{tabular}{|c|c|c|}
\hline \multicolumn{2}{|c|}{ Table: 3.2 Variables and Data Source (1972-2017) } & \multirow[b]{2}{*}{ Data Source } \\
\hline Variable & Definition & \\
\hline Aid & $\begin{array}{l}\text { Official Development Assistance } \\
\text { (\% of GDP) }\end{array}$ & World Bank, (2017) \\
\hline Y & Per capital GDP (USD, Constant) & World Bank, (2017) \\
\hline FDI & $\begin{array}{l}\text { Foreign Direct Investment ( } \% \text { of } \\
\text { GDP) }\end{array}$ & World Bank, (2017) \\
\hline $\mathrm{Gx}$ & $\begin{array}{l}\text { Government Expenditure (\% of } \\
\text { GDP) }\end{array}$ & World Bank, (2017) \\
\hline $\mathrm{L}$ & Labour Force & World Bank, (2017) \\
\hline To & Trade Openness (\% of GDP) & State Bank of Pakistan \\
\hline K & $\begin{array}{l}\text { Gross Fixed Capital Formation (\% } \\
\text { of GDP) }\end{array}$ & World Bank, (2017) \\
\hline M & Military Spending, (million, USD) & $\begin{array}{l}\text { SIPRI Military Database } \\
(2017)\end{array}$ \\
\hline AT & Arms Imports, (million, USD) & $\begin{array}{l}\text { SIPRI Military Database } \\
(2017)\end{array}$ \\
\hline
\end{tabular}

Table 5.1 : Foreign Aid, Conflict and Economic Growth Dynamics in

Pakistan (GMM methodology estimators)

Dependent Variable : GDP Per Capita : Sample 1972-2017

\begin{tabular}{|c|c|c|c|c|c|}
\hline & $\underline{\text { Eq } 4.1}$ & $\underline{\text { Eq } 4.2}$ & $\underline{\mathrm{Eq} 4.3}$ & $\underline{\text { Eq } 4.4}$ & $\underline{\mathrm{Eq} 4.5}$ \\
\hline \multirow[t]{2}{*}{ Intercept } & 2.7556 & $\overline{1.3421}$ & 2.5233 & 1.1246 & 1.5688 \\
\hline & $(0.0003)$ & $(0.0033)$ & $(0.0001)$ & $(0.0013)$ & $(0.0054)$ \\
\hline \multirow[t]{2}{*}{ Foreign Aid \% GDP } & -0.0796 & & -0.0516 & & -0.0245 \\
\hline & $(0.0012)$ & & $(0.0748)$ & & $(0.435) *$ \\
\hline \multirow[t]{2}{*}{ Labor Force } & 0.8092 & 0.8904 & 0.8448 & 0.9983 & 0.9718 \\
\hline & $(0.0003)$ & $(0.0001)$ & $(0.0001)$ & $(0.0001)$ & $(0.0001)$ \\
\hline \multirow{2}{*}{$\begin{array}{l}\text { Gross Fixed Capital Formation \% } \\
\text { of GDP }\end{array}$} & 0.0806 & 0.2823 & 0.1085 & 0.2466 & 0.2499 \\
\hline & -0.0809 & $(0.0082)$ & $(0.0331)$ & $(0.0017)$ & $(0.0022)$ \\
\hline \multirow[t]{2}{*}{ Foreign Direct Investment $\%$ GDP } & -0.0025 & -0.0203 & -0.0130 & -0.0270 & -0.0208 \\
\hline & $\begin{array}{l}(0.8488) \\
*\end{array}$ & $(0.0736)$ & $(0.3005)$ & $(0.0376)$ & $\begin{array}{l}(0.1404) \\
*\end{array}$ \\
\hline \multirow[t]{2}{*}{ Trade Openness } & 0.3508 & 0.4237 & 0.5059 & 0.4908 & 0.3608 \\
\hline & $(0.0323)$ & $(0.0156)$ & $(0.0079)$ & $(0.0001)$ & $(0.0001)$ \\
\hline \multirow[t]{3}{*}{ Government Expenditure \% GDP } & 0.0079 & 0.0260 & 0.0017 & 0.0092 & 0.0172 \\
\hline & $(0.5126)$ & $(0.1425)$ & $(0.8671)$ & $(0.2706)$ & $(0.0071)$ \\
\hline & $*$ & $*$ & $*$ & $*$ & $*$ \\
\hline \multicolumn{2}{|l|}{ (Conflict Index) } & $\begin{array}{l}-0.0814 \\
(0.0911)\end{array}$ & $\begin{array}{l}-0.0753 \\
(0.0503)\end{array}$ & & \\
\hline \multicolumn{2}{|l|}{ Aid-Conflict Interactive term } & & & $\begin{array}{l}-0.0108 \\
(0.0001)\end{array}$ & $\begin{array}{c}-0.0090 \\
(0.0149)\end{array}$ \\
\hline
\end{tabular}




\begin{tabular}{|c|c|c|c|c|c|c|c|c|c|}
\hline \multicolumn{10}{|l|}{ Diagnostics } \\
\hline \multicolumn{10}{|l|}{$\begin{array}{l}\text { Diagnostics } \\
\text { Prob (J-Stats) }\end{array}$} \\
\hline Square & 0.9814 & & 0.9715 & & 0.9820 & & 0.9779 & 0.9769 & \\
\hline D.W & & & & 1.56 & & 1.529 & 1.5590 & 2.2177 & 2.2746 \\
\hline
\end{tabular}

Note: $p$-values are in parenthesis,

* denotes insignificance.

Table 5.2 : Foreign Aid, Conflict and Economic Growth Dynamics in Pakistan (Fully Modified OLS)

\begin{tabular}{|c|c|c|}
\hline \multicolumn{3}{|c|}{ Dependent Variable : GDP Per Capita : Sample 1972-2017 } \\
\hline & Eq 4.3 & Eq 4.4 \\
\hline Intercept & $\begin{array}{l}3.2256 \\
(0.0001)\end{array}$ & $\begin{array}{l}3.2875 \\
(0.0001)\end{array}$ \\
\hline Foreign Aid \% GDP & $\begin{array}{l}-0.0396 \\
(0.0023)\end{array}$ & \\
\hline Labor Force & $\begin{array}{l}0.8136 \\
(0.0007)\end{array}$ & $\begin{array}{l}0.8623 \\
(0.0001)\end{array}$ \\
\hline Gross Fixed Capital Formation \% of GDP & $\begin{array}{l}0.1084 \\
(0.0092)\end{array}$ & $\begin{array}{l}0.1440 \\
(0.0044)\end{array}$ \\
\hline Foreign Direct Investment \% GDP & $\begin{array}{l}-0.0006 \\
(0.9366)\end{array}$ & $\begin{array}{l}0.0014 \\
(0.8605)\end{array}$ \\
\hline Trade Openness & $\begin{array}{l}0.2687 \\
(0.0001)\end{array}$ & $\begin{array}{l}0.2892 \\
(0.0001)\end{array}$ \\
\hline Government Expenditures ( $\%$ of GDP) & $\begin{array}{l}0.0057 \\
(0.0537)\end{array}$ & $\begin{array}{l}0.0055 \\
(0.1093)\end{array}$ \\
\hline Conflict Index & $\begin{array}{l}-0.0676 \\
(0.0041)\end{array}$ & \\
\hline Aid-Conflict Interactive term & & $\begin{array}{l}-0.3080 \\
(0.0016)\end{array}$ \\
\hline \multicolumn{3}{|l|}{ Diagnostics } \\
\hline R-Square & 0.9868 & 0.9842 \\
\hline Adjusted R-squared & 0.9843 & 0.9817 \\
\hline ADF test- Residuals & $(0.0000)$ & $(0.0000)$ \\
\hline
\end{tabular}

Note: $p$-values are in parenthesis

Table 5.3 : Foreign Aid, Conflict and Arms Imports Dynamics in Pakistan 
Dependent Variable : Arms Imports (growth rate) sample (1972-2017)

\begin{tabular}{|c|c|c|}
\hline & $\operatorname{Eq} 4.5$ & Eq 4.6 \\
\hline Intercept & $\begin{array}{c}13.1715 \\
(0.0003)\end{array}$ & $\begin{array}{l}14.3460 \\
(0.0047)\end{array}$ \\
\hline \multirow[t]{2}{*}{ Military Expenditure (\% of GDP) } & 0.2365 & 0.0121 \\
\hline & $(0.0415)$ & $(0.0113)$ \\
\hline \multirow[t]{2}{*}{ Conflict Index } & 1.6523 & \\
\hline & $(0.0020)$ & \\
\hline Foreign Aid (\% GDP) & $\begin{array}{c}0.0001 \\
(0.0810)\end{array}$ & $\begin{array}{l}0.0004 \\
(0.6852)\end{array}$ \\
\hline Interstate Conflict & & 1.7645 \\
\hline Intrastate Conflict & & $\begin{array}{l}(\mathbf{0 . 0 0 5 4}) \\
0.5394\end{array}$ \\
\hline \multirow[t]{2}{*}{ Coalition Support Fund } & 0.3835 & $\begin{array}{l}(0.7072) \\
0.0859\end{array}$ \\
\hline & $(0.2114)$ & $(0.9404)$ \\
\hline \multicolumn{3}{|l|}{ Diagnostics } \\
\hline & 0.7956 & 0.8121 \\
\hline & 0.5742 & 0.3460 \\
\hline & 2.0565 & 1.8530 \\
\hline
\end{tabular}

R-Square

Prob( J-Stats)

D.W stats

Note: $p$-values are in parenthesis 